5. Новиков А. И. Реферативный перевод научно-технических текстов / А. И. Новиков, Н. М. Нестерова. - АН СССР, Ин-т языкознания. - М. : Наука, 1991. $146 \mathrm{c}$.

УДК $378.147: 821.111$

Олеся Приймаченко

\title{
ПІДХІД ДО ВИВЧЕННЯ АНГЛОМОВНОЇ ЛЕКСИКИ КУРСАНТАМИ НЕПРОФІЛЬНОГО ВНЗ
}

Приймаченко О. М. Підхід до вивчення англомовної лексики курсантами непрофільного ВНЗ.

У статті запропоновано підхід до первинної активації незнайомої англомовної лексики 3 використанням PowerPoint-презентацій. Обгрунтовано концептуальні основи підходу та проаналізовано основні методи його реалізації.

Ключові слова:активація англомовної лексики, метод візуалізації, метод складання міні-оповідання, образ, контекст.

Приймаченко О.Н.Подход к изучению англоязычной лексики курсантами непрофильного вуза.

В статье предлагается подход активации незнакомой англоязычной лексики с использованием PowerPoint-презентаций. Описаны концептуальные основы подхода и проанализированы основные методы его реализации.

Ключевые слова:активация англоязычной лексики, метод визуализации, метод составления мини-рассказов, образ, контекст.

Pryimachenko O. M. Approach to English vocabulary learning by cadets of unspecialized High Schools.

The approach of unknown English vocabulary activation with the use of PowerPoint presentation is proposed in the article. Conceptual basics of the approach are substantiated, main methods of its realization are analized.

Key words:English vocabulary activation, method of visualization, method of storytelling, image, context.

Методика навчання іноземної мови в галузі непрофільної лінгвістичної освіти, яка склалась за останні роки у вищих навчальних закладах, накопичила грунтовний досвід методів, прийомів і форм навчання. Результатом цієї роботи, безперечно, можна вважати наявність чималої кількості посібників, підручників, методичних рекомендацій тощо. Усі вони заслуговують на позитивне ставлення та схвалення. Але, на жаль, нині в умовах стрімкого запровадження в організацію освіти інноваційних мультимедійних технологій ці здобутки важко застосувати для розв'язання завдань удосконалення мовної освіти студентів та курсантів. Тому сучасні науковці й освітяни розпочали активний пошук шляхів модернізації процесу викладання іноземних мов у вищій школі, непрофільних навчальних закладах зокрема.

Актуальним завданням у сучасній мовній підготовці 3 іноземної мови $\epsilon$ формування іншомовної комунікативної компетенції студентів (курсантів), при чому акцентується розвиток навичок спонтанного усного мовлення. Відомо, що структурною одиницею мовлення є слово. Будь-яке усне висловлювання залежить від кількості слів, наявних в активному словниковому запасі мовця. У науковій літературі це детермінується як лексична компетенція. Пошук ефективних прийомів первинної 102

Педагогіка вищої та середної школи. - 2014. - Вип. 41 
активації незнайомих іншомовних лексичних одиниць став для нас метою під час формування лексичної компетенції курсантів. У зв'язку 3 цим мета cmammiобгрунтувати підхід до первинної активації англомовної лексики курсантами непрофільного ВНЗ.

Способи та прийоми ознайомлення 3 навчальним лексичним матеріалом у своїх роботах розглядали багато дослідників та педагогів, а саме: Н. Боброва-Смирнова, В. Бухбіндер, Н. Гез, 3. Кличнікова, Б. Лапідус, А. Миролюбов, І. Павлова, І. Рахманов, C. Фоломкина, 3. Цвєткова, В. Цетлін тощо. Проблему формування іншомовної лексичної компетенції досліджували у своїх працях В. Боршовецька, М. Гаврилюк, О. Зеленська, Е. Мірошниченко, Ю. Семенчук, О. Тарнопольський, О. Хазова. Вони розробили когнітивні стратегії для поетапного навчання англійської економічної лексики; відібрали мнемічні прийоми запам'ятовування англійської економічної лексики; запровадили концепцію організації парно-групових і колективних форм мовленнєвої взаємодії з вивчення лексичного матеріалу під час виконання творчих завдань; дослідили початковий етап навчання професійної лексики студентів-економістів під час усного мовленнєвого спілкування у непрофесійних сферах комунікації.

У дослідженнях I. Баценко, I. Берман, В. Гнаткевича, Г. Китайгородської, В. Коростильова, Ю. Пассова, О. Тарнопольського, С. Шатілова, R. Ellis вивчено роботу лексичних механізмів у рецептивних та репродуктивних видах мовленнєвої діяльності, розроблено типи вправ і складено словники-мінімуми фахової лексики, висвітлено питання семантизації лексики та іiі засвоєння на різних етапах вивчення іноземної мови [3].

Автори зазначених досліджень започаткували розв'язання проблеми формування лексичної компетенції, водночас нині в умовах нових освітніх та мультимедійних технологій і методів, можливості роботи на етапі первинної активації англомовної лексики суттєво розширилися.

Тому в статті здійснено спробу обгрунтувати обраний нами підхід до вивчення незнайомої англомовної лексики на першому етапі ii активації 3 використанням презентацій у PowerPoint.

Концептуальною основою нашого підходу стало поєднання двох загальновідомих методів: методу візуалізації й методу складання міні-оповідань. Факт полегшення засвоєння іноземних слів за допомогою прийомів візуалізації, селективної уваги, асоціювання образів та складання незначних за обсягом історій доведений багатьма дослідниками (3. Девицька, А. Семін, В. Сокирко, С. Сторожук Р. Фрумкіна, К. Чигогідзе).

Отже, з'ясуємо переваги методу візуалізації або, як його ще називають, методу створення образу за первинної активації англомовної лексики.

Як слушно зауважує Л. Петрова, сучасне покоління виховується не на текстовій, а на візуальній інформації будь-якого типу. Студенти, які вивчають іноземні мови нині, краще сприймають, опрацьовують і запам'ятовують саме візуально поданий матеріал (мультимедійні навчальні програми й навчальні фільми). Подання інформації у візуальній формі забезпечує якісне нове його сприйняття та перероблення. Сприйняття будь-якої інформації розпочинається з сенсо-моторного етапу (чуттєвого сприйняття), а 80\% інформації отримується лише через зоровий аналізатор. Процес візуалізації становить звернення мисленнєвого змісту в наочний образ, який може бути розгорнутий і може слугувати опорою адекватних мисленнєвих і практичних дій. Візуалізація навчальної інформації сприяє більш інтенсивному засвоєнню матеріалу, орієнтуючи студента (курсанта) на пошук системних зв'язків і 
закономірностей [5, с. 110].

Окрім того, завдяки візуалізації незнайомий лексичний матеріал, який треба запам'ятати, легко переходить 3 короткотривалої пам'яті у довготривалу. Все те, що викликає у людини яскраву емоційну реакцію, залишає глибокий слід у свідомості і запам'ятовується міцно і надовго. Це пов'язано з такими характеристиками емоційної пам'яті, як іï мимовільність і висока швидкість переходу емоційного образу в довгострокову пам'ять без багаторазових повторень [2, с. 40].

Візуалізації чи створенню яскравого образу у нашому підході підлігає новий лексичний матеріал, структурований у змістовий контекст у формі міні-оповідання. Візуалізуються опорні лексичні терміни та фрази, які викладаються в чіткій послідовності відповідно до сюжетної лінії міні-оповідання.

Візуалізації створюються у форматі слайдів PowerPoint. Ця програма дозволяє більш повно використовувати можливості зорових аналізаторів та подавати інформацію у потрібній послідовності й у потрібних пропорціях [7, с. 104; 6, с. 100]. Завдяки функціональним можливостям цієї програми англомовна фраза чи термін можуть подаватися спочатку в образному вигляді, а потім у вербальному (графічному) або одночасно візуально й вербально.

Як попередньо зазначалось, лексичний матеріал структурується у мініоповідання. Ми звернулись до такої форми подачі тому, що саме вона дозволяє застосувати слово чи фразу у мовленнєвому висловлюванні «тут і зараз», тобто 3 перших хвилин ознайомлення 3 новим невідомим словом розпочинається безпосереднє формування англомовних комунікативних навичок.

На переваги контекстного методу у вивченні слів почав звертати увагу ще у 1989 році відомий науковець С. Гарибян, який підкреслював значення впливу швидкісного створення сюжетів при запам'ятовуванні слів на розвиток опертивності мислення. Метод створення розповіді зі змістом задля запам'ятовування на основі непов'язаних між собою слів він назвав «ланцюгом» [1].

Сучасні дослідники також схиляються до контекстного методу під час активації та вивчення нової іншомовної лексики (Г. Гринюк, 3. Девицька, Ю. Семенчук, К. Чигогідзе). Так, за результатами анкетування, здійсненого3. Девицькою, найбільш ефективним засобом уведення нових слів до досліджуваних виявилося введення слів до змістовного контексту, також контекст становив базис для встановлення значення невідомого слова [4]. Спираючись на висновки Г. Гринюка та Ю. Семенчук, І. Орищин у своєму дослідженні для семантизації термінів використав контекстуальний спосіб, підкресливши, що повторюваність лексичних одиниць у різноманітних контекстах, багаторазове зорове та слухове сприйняття сприяють закріпленню в пам'яті їх значень і вживань [3]. Провівши дослідження К. Чигогідзе підтвердив, що людина опановує більшу частину лексики засобом контексту. На основі контексту відбувається опанування в реченні наданого змісту. Змістовий контекст уважається єдиним чинником, за допомогою якого опановується значення незнайомого слова [8].

Отже, стисло розглянувши концептуальні основи підходу до первинної активації англомовної лексики, наведемо приклад реалізації окресленого підходу.

Так, узявши за основу тему «Crimes: Autotheft» 3 підручника Career Paths English: Police [9], який пропонується курсантам 1-го курсу як базовий для бакалаврів спеціальностей «Правознавство» та «Правоохоронна діяльність», ми розробили мініоповідання для первинної активації й подальшого запам'ятовуання таких англомовних слів та фраз: tourirts, visit London, a rental car, gas station, engine running, idle, teenagers, enter the car, keys in the ignition, run the engine, drive off, joyride, call the 
Police, vehicle identification number, fill the stolen vehicle bulletin, a high speed chase, fit the description, use spike strips, arrest, recover the car. Саме цей лексичний мінімум був обраний тому, що він $\epsilon$ базовим у вивченні теми уроку у зазначеному підручнику.

Наведемо приклад, як ці слова можуть бути контекстуально об'єднані у мініоповідання. Зазначимо, що кожне окреме речення 3 оповідання коментує слайд 3 образом, який презентує кожну із заначених вище англомовних фраз: 1. Last summer my friend with other tourists visited London. 2. They travelled by a rental car. 3. Once they arrived at the gas station. 4. A driver left the engine running. 5. The rental car was idling for a few minutes. 6 . Suddenly some teenagers entered the car. 7 . The keys were in the ignition. 8. Boys run the engine and drove off. 9. They stole the car for a joyride. 10. My friend called the Police immediately. 11. The police officer asked the vehicle identification number of the stolen car. 12. And filled the stolen vehicle bulletin. 13. After that the officer ordered to start a high speed chase. 14. In 5 minutes police noticed a car fit the description. 15. They had to use spike strips to stop teenagers. 16. Only after that the police arrested them. 17. And recovered the rental car to the owner.

Яскраві образи на слайдах PowerPoint, які супроводжують це оповідання, допомагають надійно закріпити нові слова у довгостроковій пам'яті. Пов'язане у свідомості слово з образом запам'ятовується набагато легше, а введення слова впевний контекст можна розглядати як його введення у план реального часового відношення. При цьому у слові розкриваються та активізуються закладені у ньому змістові ресурси.

За таким прикладом курсанти можуть складати власні оповідання, користуючись лише опорними слайдами з образами та словами.

Такий підхід ефективно застосовується як інтерактивна платформа для навчання в колективі та через колектив, оскільки забезпечує активну мовленнєву взаємодію всіх учасників навчального процесу, тобто інтерактивність. Створюється атмосфера співробітництва. При цьому курсант та викладач - рівноправні, тобто знають, уміють і здійснюють свою діяльність разом, розуміючи завдання та мету кожного окремого заняття. Варто підкреслити наявність особистісної зацікавленості курсантів у навчанні, тобто глибокої внутрішньої мотивації, 3 можливістю для їхнього інтелектуального та творчого розвитку.

Отже, обраний нами підхід до первинної активації незнайомої англомовної лексики засобами презентацій у РowerPoint на основі методів візуалізації та складання міні-оповідань дозволяє розвивати комунікативну компетентність курсантів, сприяє більш ефективному запам'ятовуванню, більш якісному опануванню лексичного матеріалу завдяки можливості застосування отриманих знань у ситуації «тут і зараз» та через дію (усне мовлення). Це досягається завдяки створенню інтерактивного середовища навчання з невимушеною атмосферою спілкування, формуванню активної позиції, відсутності психологічного бар'єру під час іншомовного спілкування.

\section{Література}

1. Гарибян С. А. Активизация мышления, развитие памяти / С. А. Гарибян. Ереван: Изд-во ИК КП Армении, 1989. - 55 с. 2. Гмызина Г. Н. Роль эмоций в обучении иностранному языку / Г. Н. Гмызина // Современные технологии обучения иностранным языкам: Международная научно-практическая конференция: сб. науч. трудов /отв. ред. Н. С. Шарафутдинова. - Ульяновск: УлГТУ, 2011. - 200 с. 3. Гринюк Г. А. Етапи формування іншомовної комунікативної компетенції у студентів економічних спеціальностей/ Г. А. Гринюк// Іноземні мови. - 2006. № 2. - С. 22-27. 4. Девицкая 3. Б. Возможности применения психолингвистических 
исследований в практике обучения второму иностранному язику / 3. Б. Девицкая // Известия Российского государственного педагогического университета им. А. И. Герцена. - $\quad$ Выпуск $\quad$ № 51. - $\quad$ 2008. - $\quad$ С. 196-201. 5. Петрова Л. М.Использование мультимедийных средств для повышения уровня усвоения учебного материала / Л. М. Петрова // Современные технологии обучения иностранным языкам: Международная научно-практическая конференция: сб.науч. трудов / отв. ред. Н. С. Шарафутдинова. - Ульяновск : УлГТУ - 2011. - 200 с. 6. Сергсєва Г. А. Викладання іноземної мови із застосуванням мультимедійних технологій: стан та проблеми / Г. А. Сергєєва // Сучасні засоби навчання іноземних мов у вищих навчальних закладах / Національний університет «Юридична академія України імені Ярослава Мудрого»/ Упорядник: Нестеренко К. В. - Харків : НУ «ЮАУім. Ярослава Мудрого», 2013. -С. 99-101. 7. Скачкова В. В. Вплив технічних засобів навчання на результативність засвоєння іноземної мови студентами / В. В. Скачкова, А. Ю. Скачкова // Сучасні засоби навчання іноземних мов у вищих навчальних закладах / Національний університет «Юридична академія України імені Ярослава Мудрого» / Упорядник :Нестеренко К. В. - Харків : НУ «ЮАУім. Ярослава Мудрого», 2013. - 132 с. 8. Чигогидзе К. 3. Постижение значения незнакомого слова посредством контекста: автореф. дис. на соискание ученой степени канд. пед. наук / К. 3. Чигогидзе. - Тбилиси, 1990. - 21 с. 9. Taylor J. Career Paths English: Police / J. Taylor, J. Dooly // United Kingdom: Express Publishing, 2011. - 60 p.

УДК 378.011.3- 051:339.13

Анатолій Путінцев

\section{ПРОБЛЕМИ ЗАСТОСУВАННЯ ПЕДАГОГІЧНОГО МОДЕЛЮВАННЯ У ПРОЦЕСІ ПРОФЕСІЙНОЇ ПІДГОТОВКИ МАЙБУТНІХ МАРКЕТОЛОГІВ}

Путінцев А. В. Проблеми застосування педагогічного моделювання у процесі професійної підготовки майбутніх маркетологів.

У статті акцентовано увагу на проблемі підвищення конкурентоспроможності випускників вищих навчальних закладів, зокрема майбутніх маркетологів, досліджено теоретичні основи педагогічного моделювання, визначено види педагогічних моделей, наведено визначення і класифікацію педагогічних моделей.

Ключові слова:модель, педагогічне моделювання, професіоналізм, маркетолог, методи активного навчання.

Путинцев А. В. Проблемы применения педагогического моделирования в процессе профессиональной подготовки будущих маркетологов.

В статье акцентировано внимание на проблеме повышения конкурентоспособности выпускников высших учебных заведений, в частности будущих маркетологов, исследованы теоретические основы педагогического моделирования, определены виды педагогических моделей, приведены определение и классификация педагогических моделей.

Ключевые слова:модель, педагогическое моделирование, профессионализм, маркетолог, методы активного обучения.

Putintsev A. V. Problems applying pedagogical modeling in the process of professional training of future marketing specialists.

In the article attention is accented on the problem of increase of competitiveness of graduating students of higher educational establishments, in particular future marketing 106

Педагогіка вищої та середної школи. - 2014. - Вип. 41 